\title{
INDOOR ENVIRONMENTAL QUALITY ASSESSMENT IN A LEARNING SPACE: UNIVERSITY OF MALAYA'S MAIN LIBRARY
}

\author{
Norhayati Mahyuddin ${ }^{*}$ and Jun Bien Law ${ }^{1}$ \\ ${ }^{1}$ Centre for Building, Construction and Tropical Architecture (BuCTA), Faculty of Built Environment, \\ University of Malaya, 50603 Kuala Lumpur, Malaysia \\ E-mail: *hayati@um.edu.my
}

\begin{abstract}
The open space concept in the modern library invokes a feeling of approachability and socialization. These open spaces are favourably designed for different usages such as individual study, group discussion, computer or laptop usage, and leisure activities. Nevertheless, questions arise whether or not these designated areas provide enough personal comfort regarding indoor environmental quality (IEQ). Are these areas equipped with good furniture layout, acoustic design features, lighting fixtures, and a mechanical ventilation system for the comfort of users? Thus, this study is to identify, evaluate, and compare different designated open space zones or areas in terms of personal comfort, perceived productivity, and health symptoms related to indoor environmental quality. The study reveals that the occupants are neither easily disturbed in terms of perceived productivity nor susceptible to any health symptoms. However, any approach to open space zoning or ergonomic adjustment has to be incorporated with measures correlated with IEQ elements in order to provide a more productive, conducive and comfortable environment.
\end{abstract}

Keywords : Indoor Environmental Quality, Library, Open Space, Indoor Comfort, Perceived Productivity

\section{INTRODUCTION}

Indoor environmental quality (IEQ) is crucial as most people carry out 80-90\% of their daily activities indoors (Giuli et al., 2012; Sarbu \& Sebarchievici, 2013). IEQ influences the health and welfare of occupants (Jaggs \& Palmer, 2000) and also affects the occupants' learning productivity (Bowden et al., 2006; Kosonen \& Tan, 2004; M. Lee et al., 2012). Satisfaction with IEQ is very much dependent on the judgment of occupants although criteria or benchmarks are mostly governed or regulated by ordinances, codes of practice etc. (Giuli et al., 2012; Wong et al., 2008). There are several main aspects of indoor environmental factors that could contribute to occupants' satisfaction which consist of lighting, air quality and aesthetic environment (Syahrul Nizam et al., 2017).

Indoor environment air quality is about all factors that has influence on health and comfortably of buildings 'occupants. This has instilled the significance of indoor environmental quality in buildings like offices, factories, hospital, classrooms, and other institutional or commercial buildings among M\&E engineers or building services managers. Poor IEQ will definitely distort the focus and attention of occupants and harm their health and welfare. Apart from that, poor IEQ could also increase building maintenance costs and lead to failure of components or defects (Jaggs et al., 2000). IEQ is a critical issue for the health and welfare of the occupants of the buildings and improved IEQ could improve the learning process and lower energy consumption (Dascalaki \& Sermpetzoglou, 2011; Jaggs et al., 2000).

Multiple research studies have been conducted previously probing the IEQ and thermal comfort of educational buildings, taking $\mathrm{CO} 2$ concentration as an IAQ surrogate. However, focus of those studies was kindergartens and pre-schools (M. C. Lee et al., 2012; Salleh et al., 2015), nurseries (Theodosiou \& Ordoumpozanis, 2008), primary and elementary schools (Montazami et al., 2012; Pegas et al., 2012; Sadick \& 
Issa, 2017; Turunen et al., 2014; Yufan \& Peter, 2010) and very few investigated university buildings (M. C. Lee et al., 2012; Sadick et al., 2017) with specific studies in the library.

\subsection{Indoor Environmental Quality in the Library}

IEQ in the library is important for the occupants such as students and workers who occupy the space for prolonged hours. IEQ related issues in the library have to be dealt with realistically as libraries have emerged to become a community place for discussions, computer usage, reading etc. (Juhnevica \& Udre, 2010; Markham, 2007; Suhaila et al., 2012). In addition, the concept of the library is being integrated with modern interior design and ergonomic approaches (Markham, 2007). Libraries are intended to provide for a wider scope of academic needs and for a diversity of preference.

Several studies have highlighted various indoor environmental quality issues related to libraries such as the library in Modena, Italy, which displayed serious Sick Building Syndrome (SBS) problems (Fantuzzi et al., 1996) and the high level of formaldehyde concentration found in university libraries in Strasbourg, France (Hanoune et al., 2006). These indoor environmental quality issues should be taken seriously and should not be neglected, as they are detrimental to the comfort and productivity of the occupants.

Research focussing on all the crucial elements of indoor environmental quality of library is rare. Righi et al. (2002) and Kim et al. (2013) have stated that an emphasis on indoor air quality is inadequate to fully assess the indoor environment. There are other elements of indoor environmental quality such as thermal comfort, lighting (Ahmad \& Maz. A, 2012) and acoustic comfort (Hickey \& Lemley. T, 2012) that play an essential role in influencing library users' behaviour and comfort. Moreover, a study by Suhaila, Anaur \& Haris (2012) focused on the design and physical environment of libraries and placed little emphasis on indoor air quality (IAQ), acoustic comfort and thermal comfort on the grounds that these elements are also the main parameters in appraising libraries' interior and physical environments. The criteria for indoor environmental quality are governed or regulated by a code of practice and require subjective feedback that allows better input such as post occupancy evaluation (POE) (Giuli et al., 2012; Wong et al., 2008). Riley, Kokkarinen and Pitt (2010) explained that POE is able to allow continuous improvement throughout a building's life cycle in terms of the provisions of IEQ and identification of other necessary technical services that cater for the needs of end users.

\subsection{Impact of Indoor Environment Quality on Productivity at learning environment}

Visual comfort and thermal comfort are mostly seen to have an impact on health and performance of students, such as influence of biological clock, eye irritations, neck and shoulder problem and temporary vision failure and totally reduce the activities and productivity of students. In addition, indoor thermal condition, sunlight heat from window; natural lighting and glare sensation from window; all can be effective on student who are living in hostel in tropical weather (Dahlan et al., 2009).

On the other hand, the time spent in the learning space also influences the productivity of students especially with a non-conducive environment. Learning performance involves mental work which relates to concentration. Hence, extreme concentration can damage acknowledgment memory and creative thinking; therefore a moderate air environment leads to lower stimulation it can paradoxically improve the performance of students that include their task in classroom (Gao et al., 2014). Therefore, IEQ in libraries must be emphasized and regarded as a serious issue since modern libraries have integrated many design changes and concepts as these will affects other aspects such as acoustic, lighting and thermal environment. This paper looks into better understanding on the problems of IEQ in a library which could influence the learning performance of the occupants as well as to find inexpensive and feasible measures to improve the conditions. 


\section{METHODOLOGY}

The main library of the University of Malaya (UM) was chosen as the case study. The library was established in 1959 and the building initially had four storeys and was located at the centre of the campus with a floor area of 17, 372 square meters as shown in Figure 1. Even though the library was established around 54 years ago, the library is technically evolved in terms of facilities provision such as wireless internet connection, scanners, online printers and electronic catalogues.

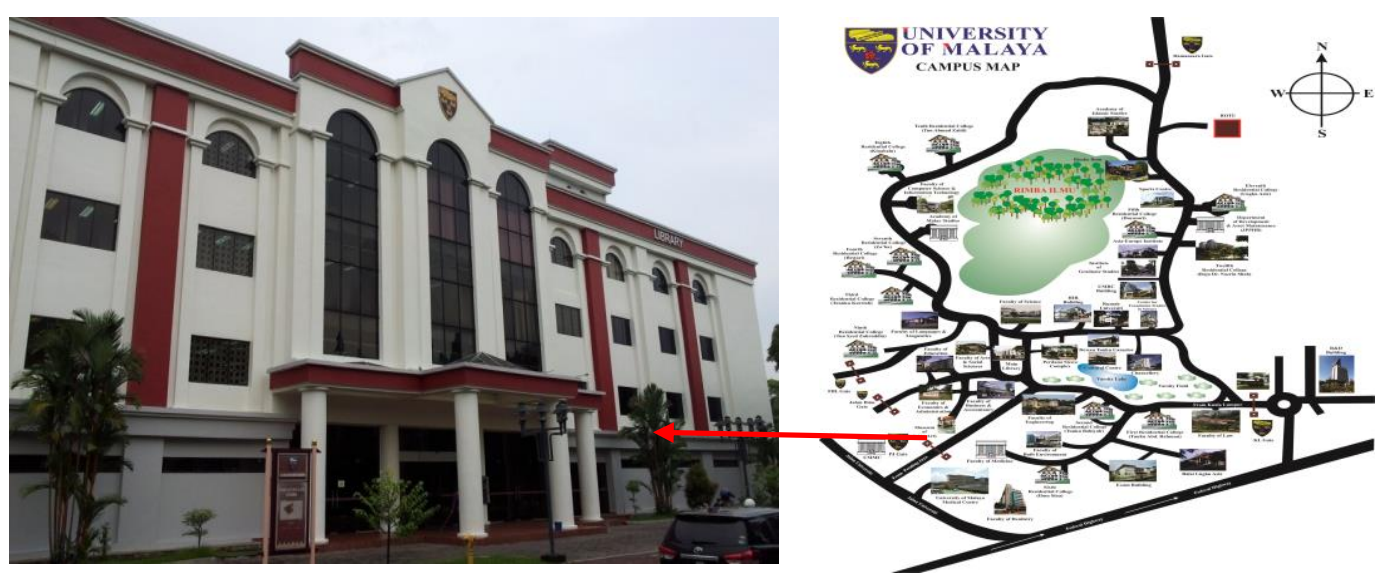

Figure 1: The façade and location of the UM main Library.

In addition, the library has designated different open space areas for specific purposes such as a green zone for discussion, blue zone for quite open study, digital corner for computer facilities, and other enclosed areas for individual study. The selection of learning environment spaces for this research was based on the three zones allocated in the library. The zones are categorized based on area and function as listed below:

1. Blue zone - Quite study or reading area (see Figure 2a)

2. Green zone - Group discussion (see Figure 2b)

3. Book shelves area - Borrowing books (see Figure 2c)

4. Digital corner - Providing computer facilities (see Figure 2d)

5. Office Room 1 - (see Figure 2e)

6. Office Room 2 - (see Figure 2f)
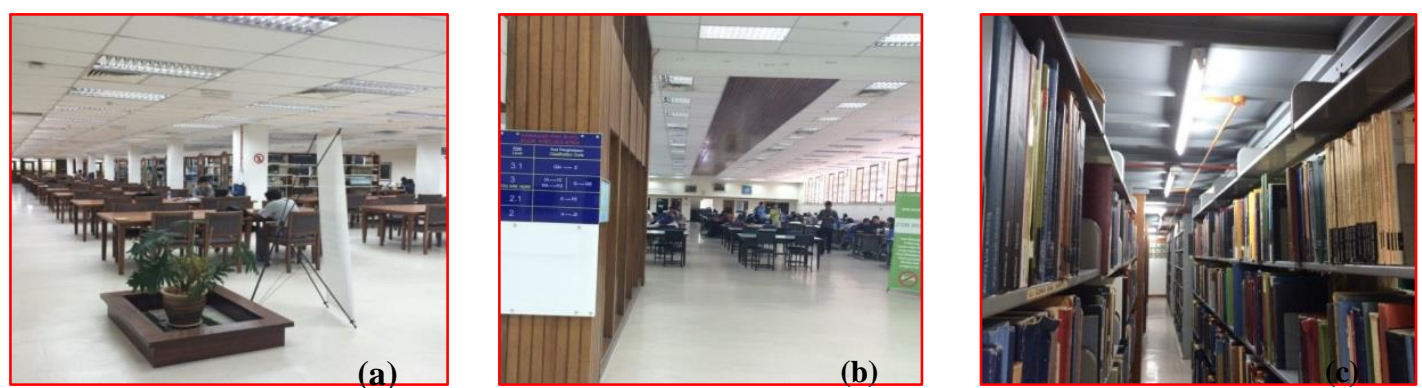

Figure 2: Selection of zones according to area and function 


\subsection{Method of Measurement}

A sound level meter and luxmeter were used to measure the level of background noise (decibel) and lighting level (Lux) respectively in the surrounding environment of the library. There were grab samplings at random spots within the boundaries of different designated areas. For measuring the indoor air quality devices were used simultaneously for data logging (see Figure 3). Both devices were used to collect measurements at different designated areas. During data logging, observations were carried out from time to time to ensure the security of the devices.
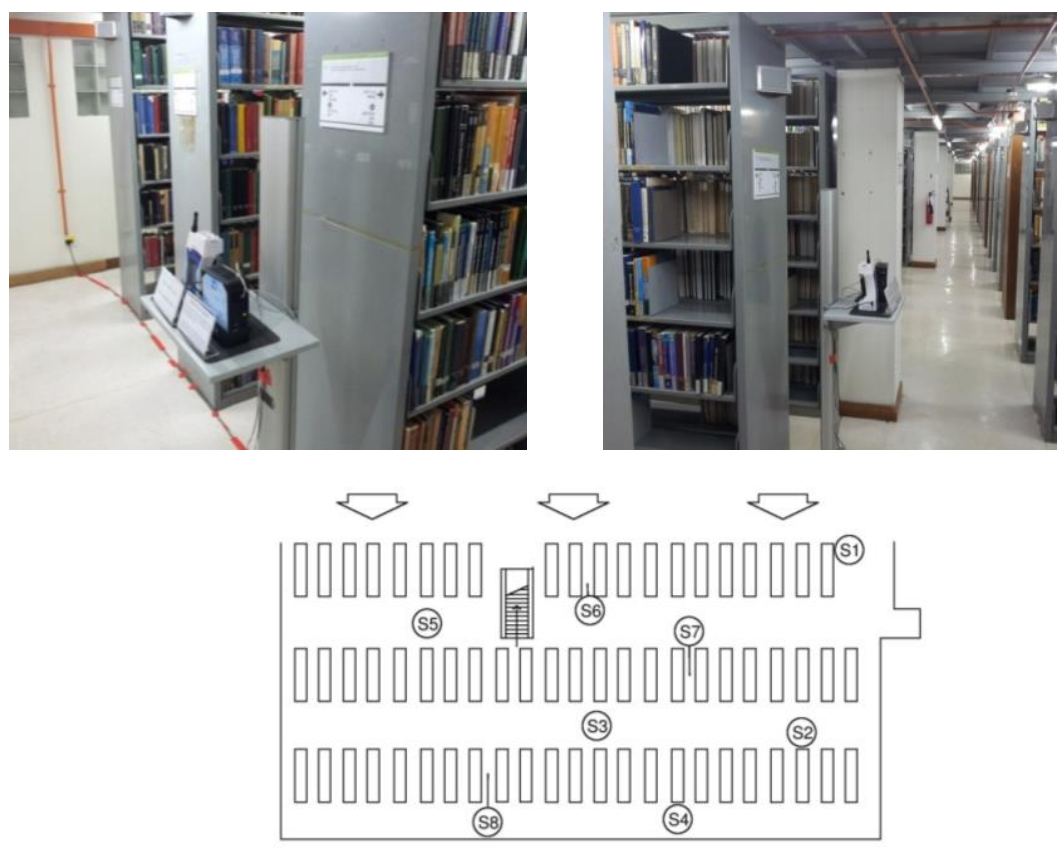

Figure 3: Positioning of YESAIR and YESDUST devices that measure IAQ in the book shelf area at spot S2, while S1 - S9 are grab sampling spots for luxmeter and sound level meter.

Post occupancy evaluation (POE) techniques such as occupant questionnaires with a 5-point Likert scale and building walk-through were employed to find out whether the indoor environment of the library catered for the needs of end users. POE is not merely used to evaluate a building that has just been completed and occupied; the POE process is extended throughout the building's life cycle to gather valuable information for continuous improvement (Riley et al., 2010).

One hundred and twenty (120) sets of questionnaires were distributed to library occupants while library staffs were given online questionnaires (35). The structured questionnaire was comprised of open-ended questions and scale ratings to gauge the occupant's perception of the indoor environmental quality in each designated open space area in the library. The research comprised literature review, questionnaire, fieldwork monitoring, and post occupancy evaluation (see Figure 4). 


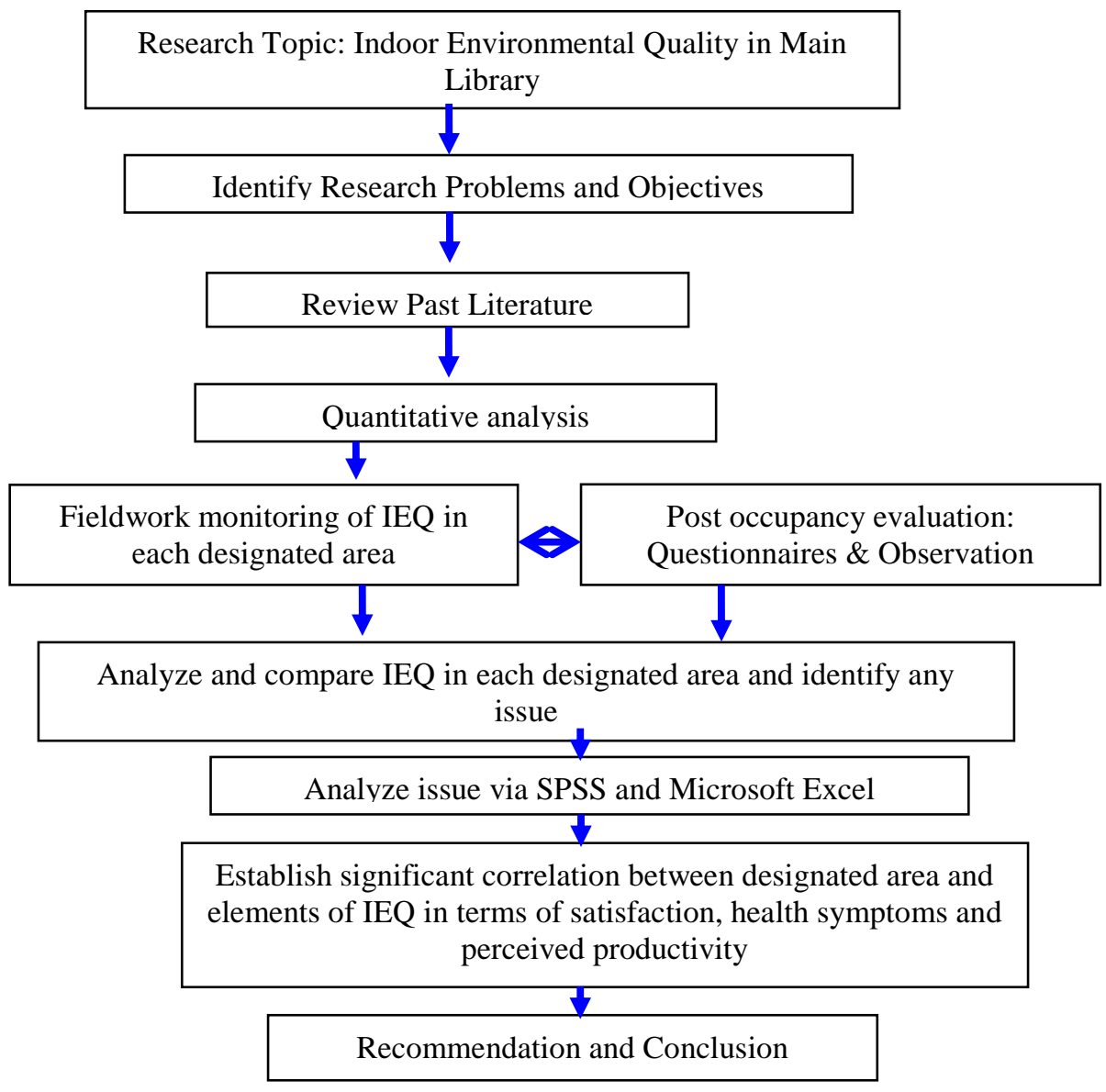

Figure 4: Summary flow chart of research methodology

\section{RESULT \& FINDINGS}

The questionnaires were distributed to respondents in the designated zones or areas in the library, and 96 questionnaires were returned by the occupants (students, researchers etc.) in the library. However, only19 librarians responded to the questionnaire online. Data which had been collected from questionnaire and sampling devices will be statistically analyzed using software like Statistical Package for the Social Sciences (SPSS) and Microsoft Excel. Descriptive analysis and correlation between variables will be used to analyze the data. The data are all nominal and ordinal, therefore non-parametric test will be carried out to analyze and compare the designated areas for any significant difference in terms of satisfaction, perceived learning productivity and health symptoms. Chi-square test will be applied as the test is able to identify the significant correlation between dependent and independent variables.

\subsection{Issues on Illuminance in the Library}

The pattern of lighting level in the blue zone is well balanced at the range 300++ lux. Referring to Arup (2007), the blue zone is deemed to have a good visual environment. Likewise, illuminance at each row of desks in green zone is perfectly balanced and the zone has incorporated natural lighting. Similar to the findings from the questionnaires, blue zone $(87.9 \%)$ and green zone $(81 \%)$ has significantly higher percentage of satisfaction on amount of light and visual comfort compared to digital corner $(52.4 \%)$.

Based on the measured illuminance level in the digital corner, an averaged value of 74.8 lux were noted which is astonishingly lower than the recommended illuminance standards by Ontario Ministry of Labour (2010) The imposed guidelines should assure that computer desk area should be illuminated around $300-500$ lux. Task 
using computers are essentially required enough illuminance as lack of luminance might create health problems like blurred vision, tired eyes, headaches and etc.

\subsection{Acoustics level in different learning spaces.}

Based on analysis of the responses obtained from the respondents, $64.3 \%$ of the respondents in the green zone were satisfied with the acoustic level for items related to noise level. However in the blue, $45.5 \%$ of the respondents reported not satisfied with the acoustic level (see Table 1). The discrepancy in terms of satisfaction level on items related to noise level in the designated areas is significant as the two-sided asymptotic significance is 0.005 which is lower than 0.05 (see Table 2). The blue zone has the highest standard residual in the "dissatisfied" column and this shows that there are significantly more occupants who are not satisfied with the acoustic conditions in the blue zone. Moreover, the values of symmetric measures are more than 0.3 at the row "Phi" and "Contingency Coefficient". This implies the existence of differences between the designated areas, and the relationship is statistically significant and strong (see Table 3 ).

Conversely, the results collected from the noise level meter shows that Green zone $(56.7 \mathrm{db})$ has highest noise while blue zone $(44 \mathrm{db})$ has the lowest noise. This indicates that the occupants have accustomed to the acoustic environment in green zone and expected a mild level of noise in that area.

Table 1: Satisfaction with noise level in blue zone, green zone and digital corner.

\begin{tabular}{|c|c|c|c|c|c|}
\hline & \multicolumn{3}{|c|}{ Satisfaction on Noise Level } \\
\hline & & & Dissatisfied & Neutral & Satisfied \\
\hline \multirow[t]{9}{*}{ Location } & \multirow[t]{3}{*}{ Blue Zone } & Count & 15 & 2 & 16 \\
\hline & & $\%$ within Location & 45.5 & 6.1 & 48.5 \\
\hline & & Std. Residual & 2.2 & -1.7 & -.5 \\
\hline & \multirow{3}{*}{$\begin{array}{l}\text { Green } \\
\text { Zone }\end{array}$} & Count & 4 & 11 & 27 \\
\hline & & $\%$ within Location & 9.5 & 26.2 & 64.3 \\
\hline & & Std. Residual & -2.1 & 1.1 & .8 \\
\hline & \multirow{3}{*}{$\begin{array}{l}\text { Digital } \\
\text { Corner }\end{array}$} & Count & 6 & 5 & 10 \\
\hline & & $\%$ within Location & 28.6 & 23.8 & 47.6 \\
\hline & & Std. Residual & .2 & .5 & -.5 \\
\hline \multirow{2}{*}{\multicolumn{2}{|c|}{ Total }} & Count & 25 & 18 & 53 \\
\hline & & $\%$ in Library & 26.0 & 18.8 & 55.2 \\
\hline
\end{tabular}

Table 2: SPSS result indicating chi-square test which correlated with Table 2

\begin{tabular}{|l|c|c|c|}
\hline Chi-Square Tests \\
\hline Pearson Chi-Square & Value & df & Asymp. Sig. (2-sided) \\
\hline Likelihood Ratio & $\mathbf{1 4 . 7 0 4 a}$ & $\mathbf{4}$ & $\mathbf{. 0 0 5}$ \\
\hline Linear-by-Linear Association & 16.106 & 4 & .003 \\
\hline N of Valid Cases & 1.095 & 1 & .295 \\
\hline 1 cells $(11.1 \%)$ have expected count less than 5. The minimum expected count is 3.94.
\end{tabular}


Table 3: SPSS result indicating symmetric measures which correlated with Table 2

\begin{tabular}{|c|c|c|c|}
\hline \multicolumn{4}{|c|}{ Symmetric Measures } \\
\hline & & Value & Approx. Sig. \\
\hline \multirow{3}{*}{$\begin{array}{l}\text { Nominal by } \\
\text { Nominal }\end{array}$} & Phi & .391 & .005 \\
\hline & Cramer's V & .277 & .005 \\
\hline & Contingency Coefficient & .364 & .005 \\
\hline \multicolumn{2}{|c|}{$\mathrm{N}$ of Valid Cases } & 96 & \\
\hline \multicolumn{4}{|c|}{ a. Not assuming the null hypothesis. } \\
\hline \multicolumn{4}{|c|}{ b. Using the asymptotic standard error assuming the null hypothesis. } \\
\hline \multicolumn{4}{|c|}{ c. Based on normal approximation. } \\
\hline
\end{tabular}

Sampling at spots B6, B7, D4, D5 and D6 (see Figure 5) showed a great variation in decibels, due to the intermittent noises generated at the walkway and the mezzanine floor where the green zone and office areas are located. This indicates that intermittent noises, such as footsteps and voices, are generated from the adjacent areas causing disturbance to the occupants. Intermittent noise is a source of disturbance and disruption and has a bigger impact on performance and focus than continuous noise (Szalma \& Hancock P.A, 2011). This is further supported by Wonyoung, Myung-Jun, \& Hyeun Jun (2018) which also indicate that the background noise levels as well as the room air temperature could significantly affect the acoustic perceptions of impact noise. However, the occupants were not easily disturbed by the acoustic conditions in terms of perceived productivity and health symptoms.

\section{Mezzanine Floor Green zone \& Office areas}

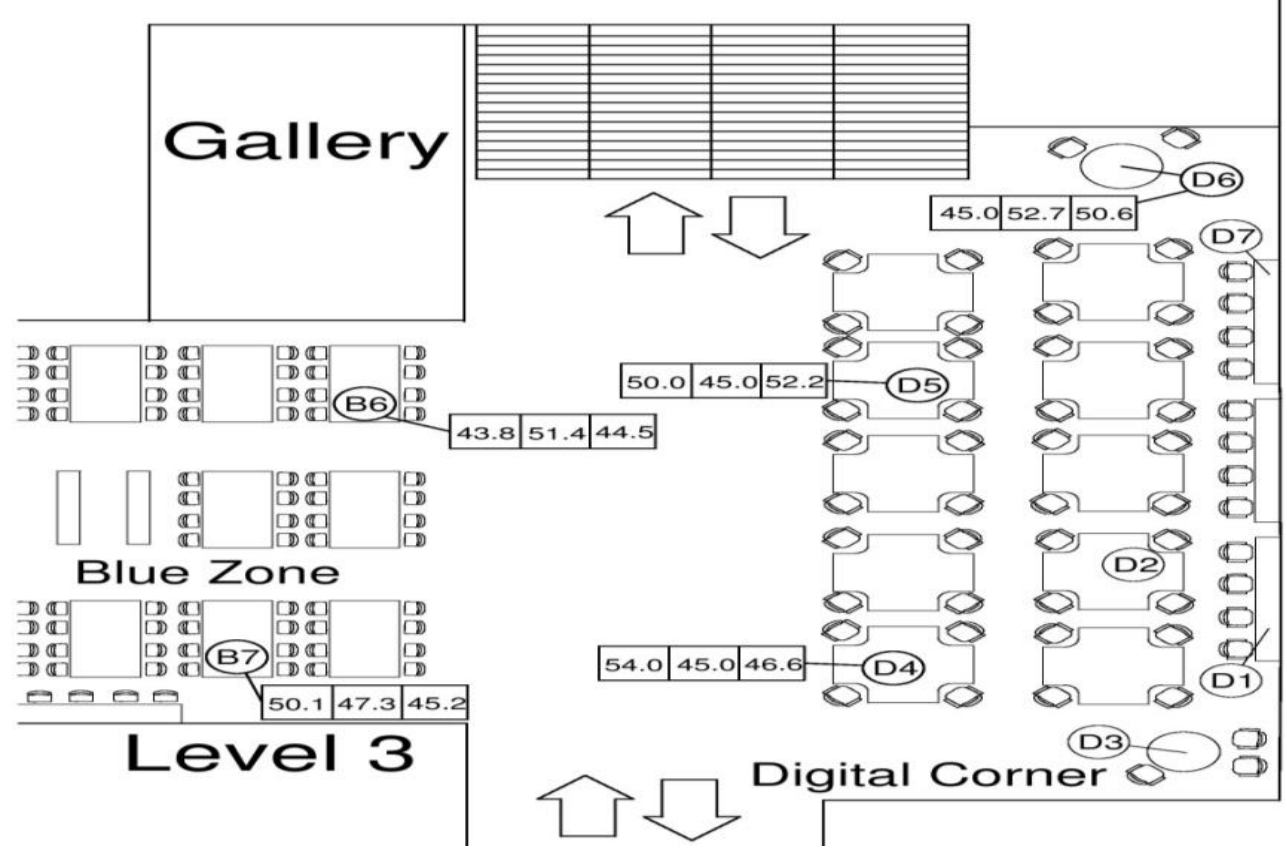

Figure 5: Grab sampling spot B6, B7, D4, D5, D6 showing three sampling data (decibels) 


\subsection{Thermal Condition in the learning environment}

Blue zone, green zone and office area have lower temperatures that averaged about $21-22^{\circ} \mathrm{C}$ compared with other areas in table 4 and these are slightly lower than the referred guidelines. Likewise, the relative humidity in each designated area is within the required range $40-70 \%$.

Table 4: Temperature and relative humidity in every designated area

\begin{tabular}{|l|l|l|l|l|l|l|}
\hline & \multicolumn{2}{l}{ Morning } \\
& \multicolumn{2}{l}{ (08:00-13:00) } & \multicolumn{2}{l|}{$\begin{array}{l}\text { Afternoon } \\
(13: 00-18: 00)\end{array}$} & \multicolumn{2}{l|}{$\begin{array}{l}\text { Evening } \\
(18: 00-22: 30)\end{array}$} \\
\hline Elements & Temperature & RH & Temperature & RH & Temperature & RH \\
\hline Green zone & 22.5 & $58.8 \%$ & 22.6 & $58.2 \%$ & 22.2 & $58.0 \%$ \\
\hline Blue zone & 21.3 & $66.9 \%$ & 20.8 & $63.2 \%$ & 21.3 & $67.8 \%$ \\
\hline Digital corner & 23.2 & $54.7 \%$ & 23.7 & $55.7 \%$ & 23.7 & $55.1 \%$ \\
\hline Book shelve & 24.5 & $59.5 \%$ & 24.6 & $59.0 \%$ & 24.6 & $59.3 \%$ \\
\hline Office area 1 & 23.0 & $54.9 \%$ & 22.0 & 55.8 & & \\
\hline Office area 2 & 20.4 & $62.6 \%$ & 20.3 & $62.6 \%$ & & \\
\hline
\end{tabular}

Similarly to the measured data, majority of the occupants in office area, blue zone and green zone have expressed that the thermal comfort is cold (see Figure 6). Since the relative humidity in each designated area does not exceed extreme condition and the temperature is within the range or near the comfort zone, thermal comfort of normal clothed person cannot be affected (Hensen, 1990). Thus, there is a probability that air movement velocity in the library areas that caused thermal discomfort.

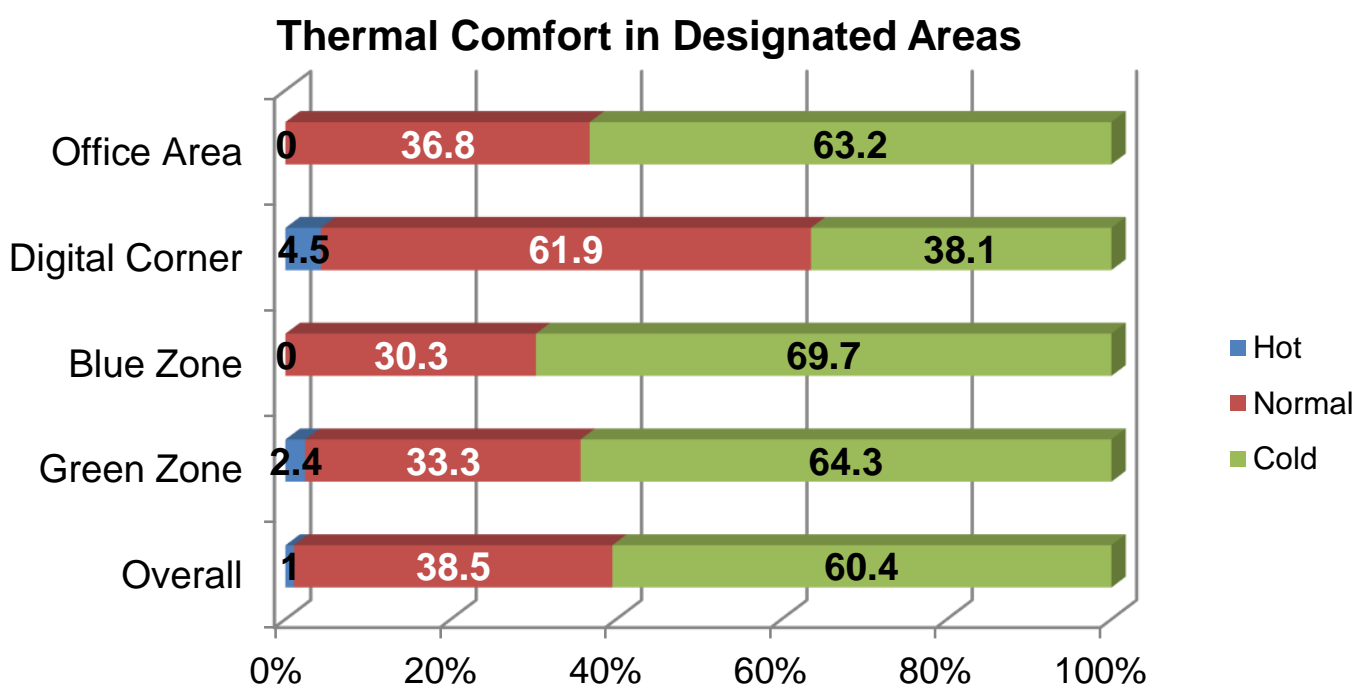

Figure 6: Bar chart shows the thermal comfort in all designated areas 


\subsection{Level of Dust Particles in the Library.}

In most areas of the library zone the dust level of $\mathrm{PM}_{10}$ are noted to be within the threshold limit of the standards except for the green zone. However, $\mathrm{PM}_{10}$ in the green zone exceeded the maximum limit of 0.15 $\mathrm{mg} / \mathrm{m}^{3}$ imposed by ASHARE (see Table 5). Data collection in the green zone was carried out during the exam period and there were approximately 80-100 occupants. Hereafter, results of IAQ will focus only in the green zone area.

Table 5: Issues found in green zone regarding particulates and carbon dioxide.

\begin{tabular}{|l|l|l|}
\hline \multirow{2}{*}{ Time } & Particulate $(\mathrm{PM} \mathrm{10})\left(\mathrm{mg} / \mathrm{m}^{3}\right)$ \\
\cline { 2 - 3 } & Average & $($ Min-Max $)$ \\
\hline $11: 00-13: 00$ & 0.209 & $(0.122-0.451)$ \\
\hline $13: 00-18: 00$ & 0.201 & $(0.043-0.598)$ \\
\hline $18: 00-22: 30$ & 0.189 & $(0.054-0.412)$ \\
\hline
\end{tabular}

One of the main causes of the high concentration of particulate $\left(\mathrm{PM}_{10}\right)$ in the green zone is the large number of occupants and physical activities in the area. This is mainly due to the dust particles brought in by the occupants, which contribute to the indoor dust (Fantuzzi et al., 1996). Moreover, the green zone is an area for group discussion and interaction; thus an increase in the volume of particles is also due to the physical movement of the occupants (Lee \& Chang M, 2000).

Human physical activities and occupant density contribute to the concentration of PM10 (see Figure 3). This particular result is similar to that in a study by Chitra \& Nagendra (Chithra \& Shiva Nagendra S, 2012) that occupants' physical activities can induce turbulence and prompt delayed deposition of PM10, thus creating an instant hike in concentration. There were sudden hikes or increases during 13:00 - 14:00 and 18:00 - 19:00 (see Figure 6) as these periods might have been lunch time and dinner time respectively.

\subsection{Significant Health Symptoms found in Green Zone}

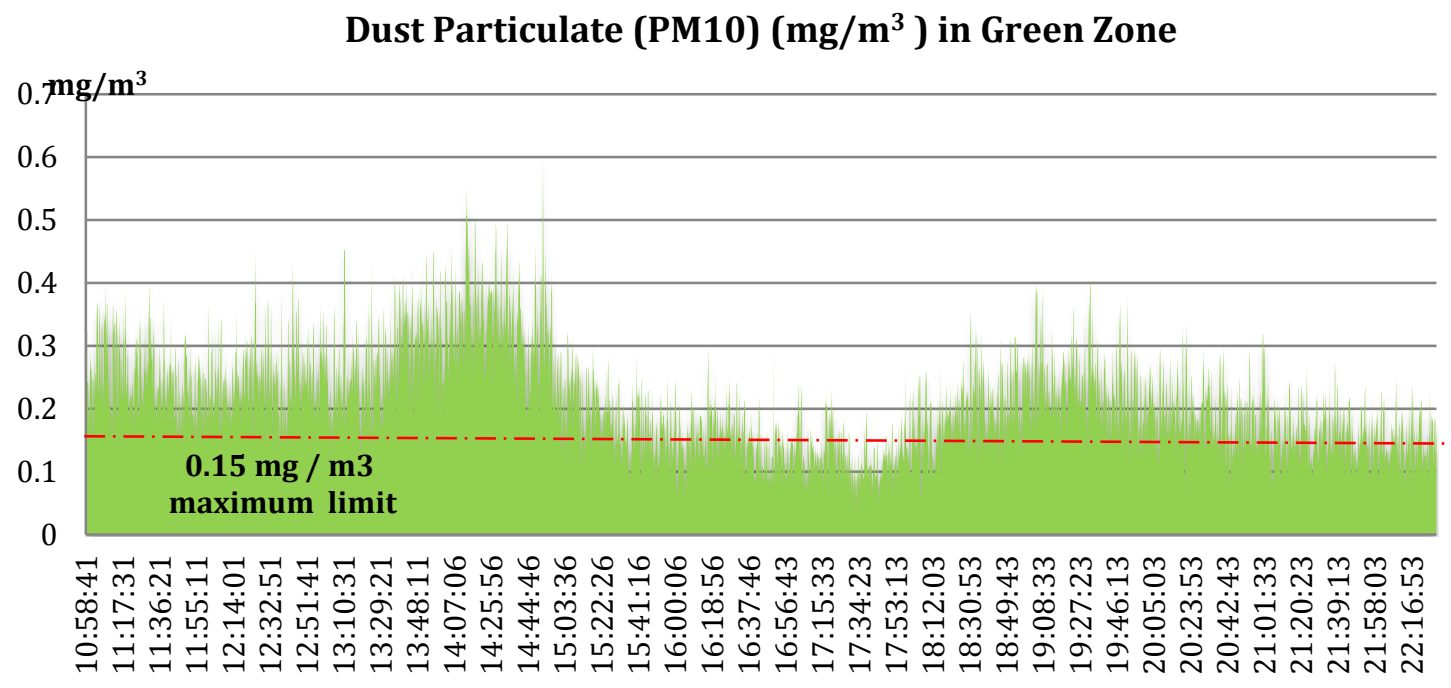

Duration

Figure 6: Chart indicating the concentration of PM 10 throughout the day in green zone 


\subsection{Significant Health Symptoms found in Green Zone}

Considering the high PM10 concentration issue in the green zone, several correlated health symptoms were found more noticeable when compared with other areas. Health symptoms such as breathing difficulties, cough, dry skin, sore throat, itchy and running noise were found to be more noticeable in the green zone (see Figure 7). Dust particulates (PM10) can infect the lungs, throat and nose (ASHRAE Standard 62, 2010)

Health Symptoms related to Indoor Environmental Quality in different Areas

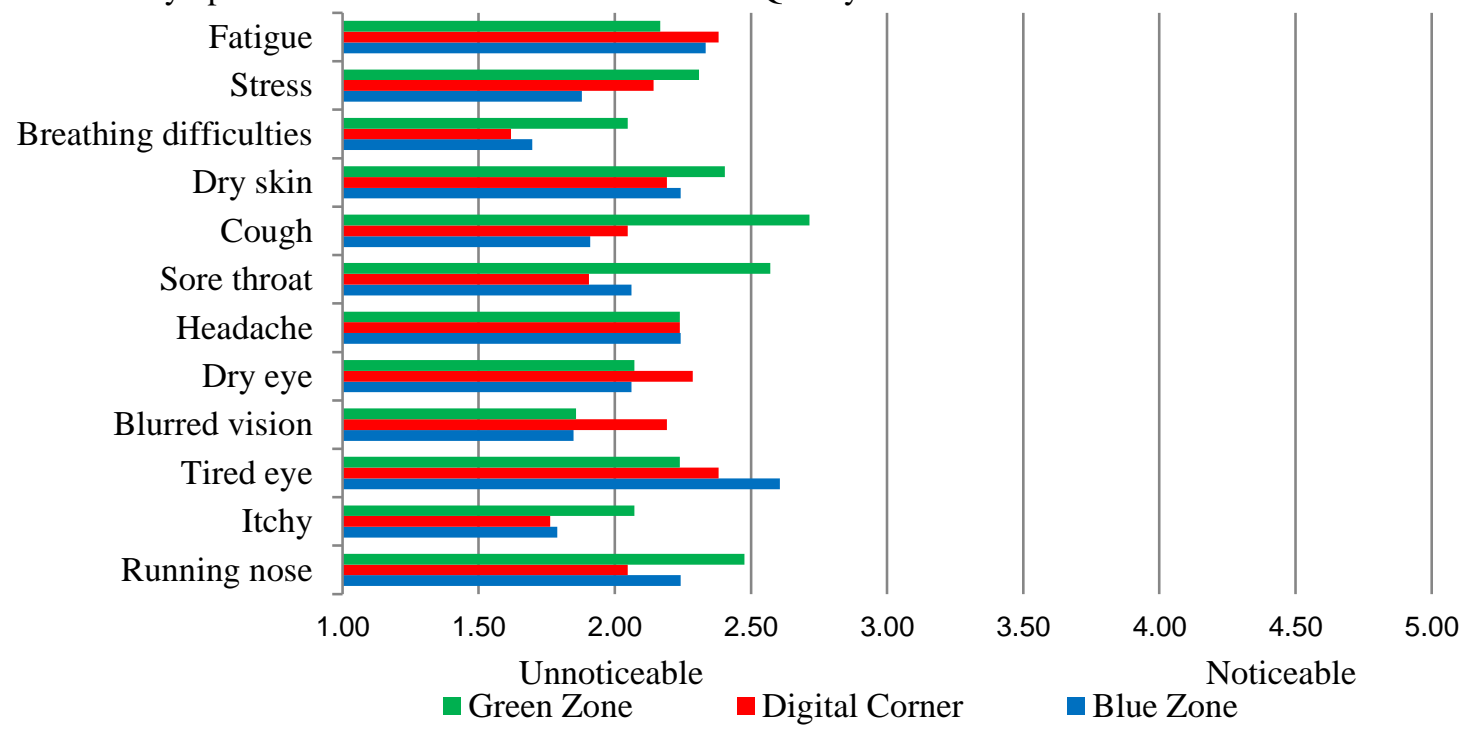

Figure 7: Notification of health symptoms related to IEQ in all designated areas.

The health symptom "cough" is significantly more noticeable among the users in the green zone with $33.3 \%$ (see Table 5). The chi-square test shows that the asymptotic significance value is 0.028 which is lower than 0.05 (see Table 6). This has established that there is a significant difference when comparing the green zone with other designated areas in terms of coughing.

Table 5: Cough symptoms in different designated areas

\begin{tabular}{|c|c|c|c|c|}
\hline & & & \multicolumn{2}{|c|}{ Health Symptoms Cough } \\
\hline & & & Unnoticeable and normal & Noticeable \\
\hline \multirow[t]{12}{*}{ Location } & \multirow[t]{4}{*}{ Blue Zone } & Count & 29 & 4 \\
\hline & & Expected Count & 26.1 & 6.9 \\
\hline & & $\%$ within Location & $87.9 \%$ & $12.1 \%$ \\
\hline & & Std. Residual & .6 & -1.1 \\
\hline & \multirow[t]{4}{*}{ Green Zone } & Count & 28 & 14 \\
\hline & & Expected Count & 33.3 & 8.8 \\
\hline & & $\%$ within Location & $66.7 \%$ & $33.3 \%$ \\
\hline & & Std. Residual & -.9 & 1.8 \\
\hline & \multirow{4}{*}{$\begin{array}{l}\text { Digital } \\
\text { Corner }\end{array}$} & Count & 19 & 2 \\
\hline & & Expected Count & 16.6 & 4.4 \\
\hline & & $\%$ within Location & $90.5 \%$ & $9.5 \%$ \\
\hline & & Std. Residual & .6 & -1.1 \\
\hline \multirow{3}{*}{\multicolumn{2}{|c|}{ Total }} & Count & 76 & 20 \\
\hline & & Expected Count & 76.0 & 20.0 \\
\hline & & $\%$ within Location & $79.2 \%$ & $20.8 \%$ \\
\hline
\end{tabular}


Table 6: Chi square tests correlated with Table 6

\begin{tabular}{|c|c|c|c|}
\hline \multicolumn{4}{|l|}{ Chi-Square Tests } \\
\hline & Value & $\mathrm{f}$ & Asymp. Sig. (2-sided) \\
\hline Pearson Chi-Square & $7.126 a$ & 2 & .028 \\
\hline Likelihood Ratio & 7.202 & 2 & .027 \\
\hline $\begin{array}{l}\text { Linear-by-Linear } \\
\text { Association }\end{array}$ & .029 & 1 & .866 \\
\hline $\mathrm{N}$ of Valid Cases & 96 & & \\
\hline
\end{tabular}

Overall, comparisons were made between the designated areas regarding satisfaction, health symptoms and disturbance to determine any gaps or explicit criteria according to the provisions of IEQ (see Figure 7). The provision of internet facilities and WiFi enabled the library to function as an online-research area or online-study area. Hence, wireless technology has somehow obscured the function or specific purpose of each designated area. Library users tend to have a quiet workstation or solitary online study or research space in the green zone which is inappropriate; this is because the green zone is designated for group discussion where a mild level of noise is allowed.

Table 7: Summary of supply, demand and gap analysis of IEQ in the library.

\begin{tabular}{|c|c|c|c|c|}
\hline \multicolumn{3}{|c|}{$\begin{array}{l}\text { Supply: Provision of IEQ in each } \\
\text { designated area }\end{array}$} & \multicolumn{2}{|c|}{$\begin{array}{l}\text { Demand : Result on satisfaction of the } \\
\text { indoor environment, notification of } \\
\text { health symptoms and interference on } \\
\text { perceived productivity in each } \\
\text { designated area }\end{array}$} \\
\hline \multirow[t]{2}{*}{$\begin{array}{l}\text { Green } \\
\text { zone }\end{array}$} & \multicolumn{2}{|c|}{$\begin{array}{l}\text { High noise level } \\
\text { (Average: } 56.7 \text { decibels) }\end{array}$} & \multirow[t]{2}{*}{$\begin{array}{l}\text { Green } \\
\text { zone }\end{array}$} & $\begin{array}{l}\text { Good satisfaction on acoustic } \\
\text { level }\end{array}$ \\
\hline & \multicolumn{2}{|c|}{$\begin{array}{l}\text { High PM } 10 \\
\text { concentration (Exceeds } \\
0.15 \mathrm{mg} / \mathrm{m}^{3} \text { ) }\end{array}$} & & $\begin{array}{l}\text { Higher health symptoms } \\
\text { compared with other areas }\end{array}$ \\
\hline $\begin{array}{l}\text { Digital } \\
\text { corner }\end{array}$ & \multicolumn{2}{|c|}{$\begin{array}{l}\text { Low level of lighting level } \\
\text { (74.8 lux) }\end{array}$} & $\begin{array}{l}\text { Digital } \\
\text { corner }\end{array}$ & $\begin{array}{l}\text { Lower satisfaction on lighting } \\
\text { level }\end{array}$ \\
\hline $\begin{array}{l}\text { Blue } \\
\text { zone }\end{array}$ & \multicolumn{2}{|c|}{$\begin{array}{l}\text { Low noise level } \\
\text { (Average: } 44.7 \text { decibels } \\
\text { but intermittent noises } \\
\text { can be heard from } \\
\text { adjacent areas) }\end{array}$} & $\begin{array}{l}\text { Blue } \\
\text { zone }\end{array}$ & $\begin{array}{l}\text { Significantly lower satisfaction } \\
\text { on acoustic level. }\end{array}$ \\
\hline \multicolumn{5}{|c|}{$\begin{array}{l}\text { Gap: What are the specifically required IEQ's elements in each designated } \\
\text { area? } \\
\text { What are the other technical services or facilities that are lack of? }\end{array}$} \\
\hline \multicolumn{2}{|c|}{ Green zone } & \multicolumn{3}{|c|}{$\begin{array}{l}\text { - Provide reverberation control to prevent noises } \\
\text { disturbing other quiet areas } \\
\text { Provide better IAQ especially PM10 as green zone is the } \\
\text { lively place with large amount of physical activities that } \\
\text { able to induce slowed deposition of PM10 and increase } \\
\text { the concentration. } \\
\text { - Crucial IEQ elements : IAQ and acoustic }\end{array}$} \\
\hline \multicolumn{2}{|c|}{ Blue zone } & \multicolumn{3}{|c|}{$\begin{array}{l}\text { - Require sound barrier or buffer zone to prevent noise } \\
\text { from adjacent areas } \\
\text { - Ergonomic adjustments with acoustic features } \\
\text { - Crucial IEQ elements : acoustic and lighting }\end{array}$} \\
\hline \multicolumn{2}{|c|}{ Digital corner } & \multicolumn{3}{|c|}{$\begin{array}{l}\text { - Required enough illuminance for computer works } \\
\text { - Crucial IEQ elements : lighting }\end{array}$} \\
\hline \multicolumn{2}{|c|}{$\begin{array}{l}\text { Other } \\
\text { technical } \\
\text { services } \\
\text { demanded }\end{array}$} & \multicolumn{3}{|c|}{$\begin{array}{l}\text { - More electrical plugs to be provided, nonetheless } \\
\text { sufficient illuminance has to be ascertained for laptop } \\
\text { usage areas }\end{array}$} \\
\hline
\end{tabular}




\section{RECOMMENDATION}

The main library of the University of Malaya is regarded as a modern library because it has implemented a zoning approach that designates specific purposes for every area. However, the indoor environmental quality in each designated area should be taken into consideration in order to provide a more comfortable, productive and conducive environment. With regard to the issue of lack of illuminance in the digital corner, the lighting design and fixture in the digital corner should be retrofitted in order to provide better illuminance (around 300 lux as specified by Illuminating Engineering Society) (Brown, 2002). Down light fitting should be used for better visual performance.

The green zone is a place for discussion and interaction and ought to be emphasised with regard to IAQ owing to the physical activities which generate a large amount of PM10 (Chithra et al., 2012). Therefore, the ventilation system in the green zone has to be assessed and modified in terms of the dust filtering mechanism, and an extractor fan might be a wise solution for extracting dust particles.

Apart from that, it was found that the level of satisfaction with items related to acoustic level in the blue zone was significantly lower due to intermittent noises such as footsteps, voices, equipment noise etc. that can be easily heard, and the majority of these noises are generated by the miscellaneous activities at the adjacent walkway, digital corner, and the mezzanine floor between level 3 and level 4. Poor reverberation at the mezzanine floor is one of the factors that the sound generated is not being absorbed effectively (Kuttruff, 2009). Hence, in order to have less reverberation and good acoustics, there should be a large enough buffer zone or sound barrier. Book shelves which were originally located in the middle of the blue zone could be shifted or rearranged to the edge of the zone (see Figure 8). Thus, these book shelves could act as an efficient sound barrier against noise (Kuttruff, 2009; Markham, 2007). Moreover, adequate electrical plugs should be supplied and sufficient luminance be provided as well for any laptop usage areas. However, due to the specific spatial features and the situations each academic library has within a particular institution, these suggestions are rather general guidelines than specific solutions.

\section{Level 3 (not to scale)}

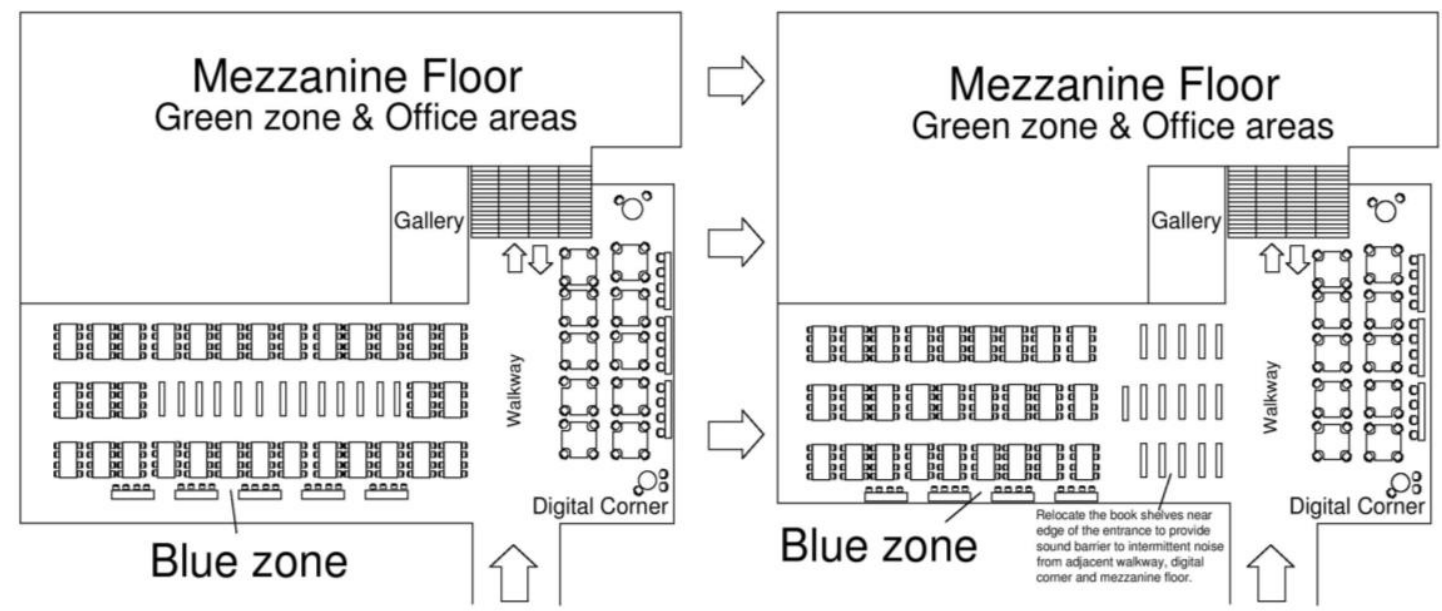

Figure 8: Relocation of book shelves in the blue zone at level 3 to provide an efficient sound barrier.

\section{CONCLUSION}

The general perception of the level of indoor environmental quality in the main library of the University of Malaya was moderate. However, several issues were identified when comparing the designated areas such as:

a) Lack of illuminance in the digital corner in accordance with guidelines.

b) A significantly higher level of dissatisfaction in terms of noise level in the blue zone due to intermittent noise compared with other areas. 
c) A high concentration of dust particulate (PM10) in the green zone in excess of the specified limits.

d) Higher notification of coughing as a health symptom in the green zone.

However, the occupants were neither easily disturbed in terms of perceived productivity nor susceptible to any health symptoms. Moreover, there were no significant differences in terms of perceived productivity and susceptibility to health symptoms between the designated areas. Coughing was found to be significantly higher in the green zone compared with other areas.

POE has identified that sufficient plugs and sockets for laptop usage should be provided due to the need for online research or study via portable laptops. Nonetheless, sufficient illuminance has to be ascertained for laptop usage areas to ensure visual comfort. In conclusion, any zoning approach or interior design changes in a library have to be integrated with measures related to indoor environmental quality.

\section{REFERENCES}

Ahmad, R., \& Maz. A. (2012). Influences of Daylighting towards Readers' Satisfaction at Raja Tun Uda Public Library, Shah Alam. Social and Behavioral Science, 68, 244-257.

ASHRAE Standard 62. (2010). Ventilation of Acceptable Indoor Air Quality. Atlanta, GA: American Society of Heating Refrigerating and Air Conditioning Engineers.

Bowden, E. E., Choiniere, M., Errett, J., \& Wang, L. M. (2006). Effects of Noise on Productivity : Does Performance Decrease Over Time? . Faculty Publication, Department of Architectural Engineering, Unversity of Nebraska, Lincoln.

Brown, C. (2002). Interior design for libraries. Chicago London: American library association.

Chithra, V., \& Shiva Nagendra S. (2012). Indoor air quality investigations in a naturally ventilated school building located close to an urban roadway in Chennai, India. Building And Environment, 54, 159--167.

Dahlan, N. D., Jones, P. J., Alexander, D. K., Salleh, E., \& Alias, J. (2009). Evidence base prioritisation of indoor comfort perceptions in Malaysian typical multi-storey hostels. Building And Environment, 44(10), 21582165. doi:https://doi.org/10.1016/j.buildenv.2009.03.010

Dascalaki, E., \& Sermpetzoglou, V. (2011). Energy performance and indoor environmental quality in Hellenic schools. Energy and Buidlings, 43, 718-727.

Fantuzzi, G., Aggazzotti, G., Righi, E., Cavazzuti, L., Predieri, G., \& Franceschelli, A. (1996). Indoor air quality in the university libraries of Modena (Italy). 193, 49-56.

Gao, J., Wargocki, P., \& Wang, Y. (2014). Ventilation system type, classroom environmental quality and pupils' perceptions and symptoms. Building And Environment, 75, 46-57. doi:https://doi.org/10.1016/j.buildenv.2014.01.015

Giuli, V., Pos, O., \& Carli, M. (2012). Indoor environmental quality and pupil perception in Italian primary schools. Building And Environment, 56, 335-345.

Hanoune, B., Lebris, T., Allou, L., March, \& Le Calve, S. (2006). Formaldehyde measurements in libraries: Comparison between infrared diode laser spectroscopy and a DNPH-derivatization method. Atmospheric Environment, 40(30), 5768--5775.

Hickey, S., \& Lemley. T. (2012). Background Noise Acceptance and Personality Factors Involved in Library Environment Choices by College Students. The Journal of Academic Librarianship, 38(6), 365-369.

Jaggs, M., \& Palmer, J. (2000). Energy performance indoor environmental quality retrofit - a European diagnosis and decision making method for building refurbishment. Energy and Buildings, 31(2), .97-101. 
Juhnevica, E., \& Udre, D. (2010). Libraries Designed for Users" Nowadays Concept of Library Architecture and Interior. BOBCATSSS 2010 @ Parma, Italy.

Kim, J., Kim, S., Lee, K., Yoon, D., Lee, J., \& Ju, D. (2013). Indoor aldehydes concentration and emission rate of formaldehyde in libraries and private reading rooms. Atmospheric Environment, 71, 1-6.

Kosonen, R., \& Tan, F. (2004). The effect of perceived indoor air quality on productivity loss. Energy and Buildings, 36, 981-986.

Kuttruff, H. (2009). Room Acoustic (Vol. 5th edition). New York: Taylor \& Francis Group.

Lee, M., Mui, K., Wong, L., Chan, W., Lee, E., \& Cheung, C. (2012). Student learning performance and indoor environmental quality (IEQ) in air-conditioned university teaching rooms. Building And Environment, 49, 238-244.

Lee, M. C., Mui, K. W., Wong, L. T., Chan, W. Y., Lee, E. W. M., \& Cheung, C. T. (2012). Student learning performance and indoor environmental quality (IEQ) in air-conditioned university teaching rooms. Building And Environment, 49, 238-244. doi:https://doi.org/10.1016/j.buildenv.2011.10.001

Lee, S., \& Chang M. (2000). Indoor and outdoor air quality investigation at schools in Hong Kong. Chemosphere, 40, 109-113.

Markham, B. (2007). Acoustic Comfort In Open Plan Library Spaces. Paper presented at the 19th International Congress on Acoustics, Madrid, Spain, 2-7 September.

Montazami, A., Wilson, M., \& Nicol, F. (2012). Aircraft noise, overheating and poor air quality in classrooms in London primary schools. Building And Environment, 52, 129-141. doi:https://doi.org/10.1016/j.buildenv.2011.11.019

Ontario Ministry of Labour. (2010). Lighting - Computer Ergonomics2016(22 July).

Pegas, P. N., Nunes, T., Alves, C. A., Silva, J. R., Vieira, S. L. A., Caseiro, A., \& Pio, C. A. (2012). Indoor and outdoor characterisation of organic and inorganic compounds in city centre and suburban elementary schools of Aveiro, Portugal. Atmospheric Environment, 50,89. doi:https://doi.org/10.1016/j.atmosenv.2012.03.059

Righi, E., Aggazzotti, G., Fantuzzi, G., Ciccarese, V., \& Predieri, G. (2002). Air quality and well-being perception in subjects attending university libraries in Modena (Italy). The Science of the Total Environment, 286, 41-50.

Riley, M., Kokkarinen, N., \& Pitt, M. (2010). Assessing post occupancy evaluation in higher education facilities. Journal Of Facilities Management, 8(3), 202--213.

Sadick, A.-M., \& Issa, M. H. (2017). Occupants' indoor environmental quality satisfaction factors as measures of school teachers' well-being. Building And Environment, 119, 99-109. doi:https://doi.org/10.1016/j.buildenv.2017.03.045

Salleh, N. M., Kamaruzzaman, S. N., Riley, M., Ahmad Zawawi, E. M., \& Sulaiman, R. (2015). A quantitative evaluation of indoor environmental quality in refurbished kindergarten buildings: A Malaysian case study. Building And Environment, 94, 723-733. doi:https://doi.org/10.1016/j.buildenv.2015.11.002

Sarbu, L., \& Sebarchievici, C. (2013). Aspects of indoor environmental quality assessment in buildings. Energy and Buildings, 60, 410-419.

Suhaila, S., Anuar, T., \& Haris, H. (2012). Towards a Better Design: Physical Interior Environments of Public Libraries in Peninsular Malaysia. Social and Behavioral Science, 42, 131-143. 
Syahrul Nizam, K., Charles, O. E., Norhayati, M., Emma Marinie Ahmad, Z., Shirley Jin Lin, C., \& Nur Farhana, A. (2017). The impact of IEQ on occupants' satisfaction in Malaysian buildings. Indoor and Built Environment, 1420326X16689493. doi:10.1177/1420326X16689493

Szalma, J. L., \& Hancock P.A. (2011). Noise effects on human performance: A meta-analytic synthesis. Psychological Bulletin, 137(4), 682-707.

Theodosiou, T. G., \& Ordoumpozanis, K. T. (2008). Energy, comfort and indoor air quality in nursery and elementary school buildings in the cold climatic zone of Greece. Energy and Buildings, 40(12), 22072214. doi:https://doi.org/10.1016/j.enbuild.2008.06.011

Turunen, M., Toyinbo, O., Putus, T., Nevalainen, A., Shaughnessy, R., \& Haverinen-Shaughnessy, U. (2014). Indoor environmental quality in school buildings, and the health and wellbeing of students. International Journal of Hygiene and Environmental Health, 217(7), 733-739. doi:https://doi.org/10.1016/j.ijheh.2014.03.002

Wong, L., Mui, K., \& Hui, P. (2008). A multivariate-logistic model for acceptance of indoor environmental quality (IEQ) in offices. Building and Environment, 43(1), 1-6.

Wonyoung, Y., Myung-Jun, K., \& Hyeun Jun, M. (2018). Effects of indoor temperature and background noise on floor impact noise perception. Indoor and Built Environment, 1420326X17753708. doi:10.1177/1420326X17753708

Yufan, Z., \& Peter, B. (2010). Findings from a post-occupancy evaluation in the UK primary schools sector. Facilities, 28(13/14), 641-656. doi:10.1108/02632771011083685 